\title{
Eğitsel Oyun Yönteminin Öğrencilerin Sosyal Becerileri, Okula İlişkin Tutumları ve Fen Öğrenimi Kaygıları Üzerine Etkisi
}

\author{
Emre YILDIZ ${ }^{1 *}$, Ümit ŞİMŞEK ${ }^{2}$, Hakan ARAS ${ }^{3}$ \\ ${ }^{1,2}$ Atatürk Üniversitesi, Kazım Karabekir Eğitim Fakültesi, Erzurum, Türkiye; ${ }^{3}$ Yıldızkent \\ İMKB Ortaokulu, Erzurum, Türkiye
}

Makale Gönderme Tarihi18.05.2016 Makale Kabul Tarihi: 16.02.2017

Özet - Bu araştırma 6. sınıf Fen Bilimleri dersi "Dolaşım Sistemi” konusunun eğitsel oyun yöntemi ile öğretilmesinin öğrencilerin sosyal becerileri, okula ilişkin tutumları ve fen kaygı düzeyleri üzerine etkisini incelemek amacıyla yapılmıştır. Bu çalışmanın örneklemi, 2015-2016 eğitim-öğretim yılında Erzurum ilinin bir ilçe merkezinde MEB'e bağlı bir Ortaokulun altıncı sınıfının iki şubesinde öğrenim görmekte olan toplam 42 öğrenciden oluşmaktadır. Bu şubelerden biri seçkisiz olarak eğitsel oyun entegre edilmiş grup araştırması yönteminin uygulandığı Deney Grubu (n=20); ikincisi programa dayalı öğretimin uygulandığı Kontrol Grubu $(n=22)$ olarak belirlenmiştir. Araştırmada öntest-sontest kontrol gruplu yarı deneysel desen kullanılmıştır. Veri toplama aracı olarak, Sosyal Beceri Ölçeği, Okula İlişkin Tutum Ölçeği ve Fen Bilimleri Öğrenme Kaygı Ölçeği uygulanmıştır. Verilerin analizi aşamasında bağımsız gruplar t-testinden yararlanılmıştır. Öğrencilerin sosyal beceri, okula ilişkin tutum ve fen kaygı düzeyleri öntest puanları arasında anlamlı bir farkın olmadığı; uygulama sonunda eğitsel oyun yönteminin uygulandığı öğrencilerin sosyal beceri düzeylerinin anlamlı şekilde yüksek olduğu ve fen kaygı düzeylerinin anlamlı şekilde düşük olduğu bulunmuştur.

Anahtar kelimeler: Eğitsel oyun, sosyal beceri, okula ilişkin tutum, fen öğrenimi kaygısı.

\section{ÖZET}

Yetişkinlerin çoğu zaman boşa harcanan zaman dilimi olarak değerlendirdiği oyunlar üzerinde titizlikle çalışılarak tüm öğrencilerin aktif olarak katılabileceği, basit, anlaşı1lır, eğlenceli, ilgi çekici, farklı yetenek, beceri ve kişisel özelliklere sahip öğrenciler için uygulamada esneklik sağlayabilecek şekilde ve öğretime yönelik olarak tasarlandığında aktif öğrenme stratejisi

\footnotetext{
${ }^{*}$ Corresponding Author: Emre YILDIZ - Atatürk University, Kazım Karabekir Education Faculty, Erzurum, emre.yildiz@atauni.edu.tr
} 
kapsamında eğitsel oyun yöntemi olarak değerlendirilmektedir. Eğitsel oyun, maddi çıar sağlamaya yönelik olmadan, öğrencileri bilişsel, duyuşsal, psikomotor, fiziksel ve sosyal açılardan geliştiren, belli bir amacı olan veya olmayan, kurallı veya kuralsız olarak gerçekleştirilebilen ve öğrencilerin sürece severek ve isteyerek katıldıkları bir aktif öğrenme yöntemidir. Eğitsel oyun yöntemi eleştirel düşünme, problem çözme, yaratıcılık, hayal gücü, iletişim ve üst düzey zihinsel becerileri geliştiren, kalıcı ve anlamlı öğrenmeler gerçekleşmesini sağlayan, eğlenceli, zevkli ve ilgi çekici yönleriyle öğrencilerin dikkatini cezbetmektedir. Ortaokul öğrencilerinin gelişimsel özellikleri bakımından incelendiğinde somut işlemler dönemi ve somut işlemler döneminden soyut işlemler dönemine geçiş evrelerinde bulunmaları nedeniyle ezber yapmaya yönlendirmeden zevkli, eğlenceli, ilgi çekici, anlamlı ve kalıcı öğrenmeler gerçekleştirmelerini sağlamak için öğretme sürecinde yaparak yaşayarak öğrenme ortamı oluşturan eğitsel oyun yönteminin kullanılması büyük faydalar sağlamaktadır. $\mathrm{Bu}$ araştırma 6. sınıf Fen Bilimleri dersi "Dolaşım Sistemi” konusunun eğitsel oyun yöntemi ile öğretilmesinin öğrencilerin sosyal becerileri, okula ilişkin tutumları ve fen kaygı düzeyleri üzerine etkisini incelemek amacıyla yapılmıştır. Araştırmanın problem durumu "6. sınıf Fen Bilimleri dersi "Dolaşım Sistemi” konusunun eğitsel oyun yöntemi ve programa dayalı öğretim ile öğretilmesinin öğrencilerin sosyal becerileri, okula ilişkin tutumları ve fen kaygı düzeyleri üzerine bir etkisi var mıdır?” şeklinde belirlenmiştir. Araştırmada öntest-sontest kontrol gruplu yarı deneysel desen kullanılmıştır. Uygulamaların başlangıcında deney ve kontrol gruplarına öntest olarak Sosyal Beceri Ölçeği (SBÖ), Fen Bilimleri Öğrenme Kaygi Ölçeği (FBKÖ) ve Okula İlişkin Tutum Ölçeği (OİTÖ) uygulanmıştır. Kontrol grubunda programa dayalı öğretim uygulanırken, deney grubunda eğitsel oyun yöntemi uygulanmış ve "Eşimi Buldum” oyunu oynatılmıştır. Uygulamaların sonunda deney ve kontrol grubuna sontest olarak SBÖ, FBKÖ ve OİTÖ uygulanmıştır. Bu araştırmanın çalışma grubu, 2015-2016 eğitim-öğretim yılında Erzurum il merkezinde MEB'e bağlı bir Ortaokulun altıncı sınıfının iki şubesinde öğrenim görmekte olan toplam 42 öğrenciden oluşmaktadır. Bu şubelerden biri seçkisiz olarak eğitsel oyun yönteminin uygulandığı Deney Grubu $(n=20)$; ikincisi programa dayalı öğretimin uygulandığı Kontrol Grubu (n=22) olarak belirlenmiştir. Sosyal Beceri Ölçeği, ilköğretim öğrencilerinin temel bazı sosyal becerilerdeki gelişimlerini ölçen 20 maddelik 4'lü likert tipi bir ölçektir. Ölçeğin kapsam geçerliliği için beş uzmanın görüşüne başvurulmuş, ölçeğin istenen sosyal beceri davranışlarını ölçtüğü görülmüştür. Cronbach Alpha katsayısı 0.75 olarak bulunmuştur. Fen Bilimleri Öğrenme Kayg1 Ölçeği, ortaokul öğrencilerinin fen bilimlerine yönelik kaygılarını belirlemek amacıyla geliştirilmiştir. Geçerlik ve güvenirlik analizlerini yapmak amacıyla toplam 844 öğrenci ile çalışılmıştır. Cronbach Alpha güvenirlik katsayısı 0,85 
olarak hesaplanmıştır. Okula İlişkin Tutum Ölçeği, 11-15 yaş arası öğrencilerin okula karşı tutumlarını tespit etmek amacıyla geliştirilen 3'lü likert tipi, 5 olumlu ve 5 olumsuz olmak üzere toplam 10 adet maddeden oluşmaktadır. Cronbach Alpha güvenirlik katsayısı 0,74 olarak hesaplanmıştır. SBÖ’nin öntestinden elde edilen verilerin analiz sonuçları incelendiğinde uygulama öncesinde eğitsel oyun yöntemi $(X=60,35)$ ve programa dayalı öğretim $(X=59,64)$ uygulanan öğrencilerin sosyal beceri düzeyleri arasında istatistiksel olarak anlamlı farklılık bulunmadığ1 görülmektedir; $\left(\mathrm{t}_{(40)}=0,243 ; \mathrm{p}>0,05\right)$. SBÖ'nin sontestinden elde edilen verilerin analiz sonuçları incelendiğinde uygulama sonrasında eğitsel oyun yöntemi $(X=67,90)$ uygulanan öğrencilerin sosyal beceri düzeylerinin programa dayalı öğretim $(X=60,45)$ uygulanan öğrencilerin sosyal beceri düzeylerinden istatistiksel olarak anlamlı olarak yüksek olduğu görülmektedir; $\left(\mathrm{t}_{(40)}=2,589 ; \mathrm{p}<0,05 ; \eta^{2}=0,14\right)$. Öğrencilerin fen öğrenimine yönelik kaygı düzeylerindeki varyansın \%14'ü uygulanan yöntemden kaynaklanmaktadır. OİTÖ’nin öntestinden elde edilen verilerin analiz sonuçları incelendiğinde uygulama öncesinde eğitsel oyun yöntemi $(X=21,80)$ ve programa dayalı öğretim $(X=22,14)$ uygulanan öğrencilerin okula karşı tutum puanları arasında istatistiksel olarak anlamlı farklılık bulunmadığı görülmektedir; $\left(\mathrm{t}_{(40)}=-0,255 ; \quad \mathrm{p}>0,05\right)$. OİTÖ'nin sontestinden elde edilen verilerin analiz sonuçları incelendiğinde uygulama öncesinde eğitsel oyun yöntemi $(X=25,30)$ ve programa dayalı öğretim $(X=23,45)$ uygulanan öğrencilerin okula karşı tutum puanları arasında istatistiksel olarak anlamlı farklılık bulunmadığı görülmektedir; $\left(\mathrm{t}_{(40)}=1,687 ; \mathrm{p}>0,05\right)$. FBKÖ’nin öntestinden elde edilen verilerin analiz sonuçları incelendiğinde uygulama öncesinde eğitsel oyun yöntemi $(X=42,95)$ ve programa dayalı öğretim $(X=39,91)$ uygulanan öğrencilerin fen öğrenimine yönelik kaygı düzeyleri arasında istatistiksel olarak anlamlı farklılık bulunmadığı görülmektedir; $\left(\mathrm{t}_{(40)}=0,808 ; \mathrm{p}>0,05\right)$. FBKÖ'nin sontestinden elde edilen verilerin analiz sonuçları incelendiğinde uygulama sonrasında eğitsel oyun yöntemi uygulanan öğrencilerin fen öğrenimine yönelik kaygı düzeylerinin $(X=29,90)$ programa dayalı öğretim uygulanan öğrencilerin fen öğrenimine yönelik kaygı düzeylerinden $(\mathrm{X}=38,32)$ istatistiksel olarak anlamlı derecede düşük olduğu görülmektedir; $\left(\mathrm{t}_{(40)}=-2,800 ; \mathrm{p}<0,05 ; \eta^{2}=0,16\right)$. Öğrencilerin fen öğrenimine yönelik kaygı düzeylerindeki varyansın \%16'sı uygulanan yöntemden kaynaklanmaktadır. Yapılan araştırmada eğitsel oyun yönteminin öğrencilerin sosyal beceri ve fen bilimleri kaygı düzeyleri üzerinde olumlu etkiye sahip olduğu sonucuna ulaşılmıştır. $\mathrm{Bu}$ durumun nedeni olarak eğitsel oyunların öğrencilerin paylaşma, yardımlaşma, birlikte çalışma, diğer insanların fikirlerine saygılı olma, kurallara uyma, kişisel haklara sahip çıkma ve arkadaş edinme gibi sosyal becerileri geliştirmesi, motivasyon, derse ve okula karşı ilgi, sevgi ve tutum 
düzeyini artırma gibi yararları gösterilebilir. Literatür incelendiğinde daha çok sanal ortamda oynanan dijital oyunların eğitim alanında kullanıldığı görülmektedir. Ancak eğitimde öğrenciye kazandırılması hedeflenen temel davranışları kazandırmada öğrencilerin sınıf ortamında aktif bir şekilde oynayabileceği, bu sayede de arkadaşları ile iletişimini artırabileceği, kendilerini rahatça ifade edebilecekleri, hem duyuşsal hem de psikomotor alan hedeflerine yönelik etkinlikleri yapabilecekleri oyunların bu konuda daha etkili olacağı düşünülmektedir. Bu nedenle eğitsel oyun yöntemi Fen Bilimleri dersi müfredatında yer alan diğer konuların öğretiminde de uygulanmalıdır. 


\title{
The Effect of the Educational Game Method on Students' Social Skills, Attitude towards the School, and Sciences Learning Anxiety
}

\author{
Emre YILDIZ ${ }^{1 \dagger}$, Ümit ŞİMŞEK ${ }^{2}$, Hakan ARAS ${ }^{3}$ \\ ${ }^{1,2}$ Atatürk University, Kazım Karabekir Education Faculty, Erzurum; ${ }^{3}$ Yıldızkent İMKB \\ Secondary School, Erzurum
}

Received : 18.05.2016 Accepted : 16.02.2017

\begin{abstract}
The purpose of this research is to find out the effect of teaching "the Circulatory System" subject, which is covered in the $6^{\text {th }}$ grade Science course, through the educational game method on students' social skills, attitude to the school, and sciences learning anxiety levels. The sample of this study consists of a total of 42 students from two $6^{\text {th }}$ grade groups of a middle school in the 2015-2016 academic year in Erzurum. One of these groups was set as the experimental group in which the educational game method would be carried out $(n=20)$ while the other section was set as the control group in which program-based instruction would be conducted $(n=22)$. Pretest-posttest control group quasi-experimental design, which is an experimental research model, was used. The data were collected via the Social Skills Scale, Attitude towards School Scale and Sciences Learning Anxiety Scale. The data were analyzed via independent groups t-test. The experimental group students were seen to have significantly higher social skills and lower science learning anxiety in comparison to the control group students.
\end{abstract}

Key words: Educational games, social skills, attitude towards school, sciences learning anxiety.

\section{Introduction}

The age we live in is called the age of information and societies of this age are called the societies of information. Societies of information produce information and technology themselves and constantly develop in science. The societies who want to sustain their existence in the future are aware that they need to educate people who have scientific views of life. One of the most effective subjects for the students to gain the scientific view required in scientifically identifying the events in their environment and explaining the situaions they

\footnotetext{
${ }^{\dagger}$ Corresponding Author: Emre YILDIZ - Atatürk University, Kazım Karabekir Education Faculty, Erzurum, emre.yildiz@atauni.edu.tr
} 
encounter in their daily life is the science course. Therefore, societies are in pursuits of new things to foster the quality of science courses (Gençer \& Karamustafaoğlu, 2014; Çepni, 2011).

Since science course involves many abstract and complex subjects, it becomes very difficult for the students to understand and learn the subjects; therefore, they do not like the course, develop negative attitudes towards it and they distant from the it (Önen, 2005; Saracaloğlu \& Aldan Karademir, 2009; Çavuş, Kulak, Berk \& Öztuna Kaplan, 2011; Karamustafaoğlu \& Kaya, 2013; Kaya \& Elgün, 2015).

The method and techniques used in accordance with active learning strategy offer the effective learning environment for effective learning required in the science course. Use of active learning strategy in the classroom makes the lessons more enjoyable and interesting, facilitates learning, ensures meaningful and permanent learning, gives the learners the basic skills aimed to be given to them, and contributes to their overall development (National Academy of Sciences, 2006; Uzuntiryaki, Çakır \& Geban, 2001; Saracaloğlu \& Aldan Karademir, 2009; Sökmen, Bayram, Solan, Savcı \& Gürdal, 1997).

Games, which adults usually consider as the time spent uselessly, when designed attentively as simple, understandable, enjoyable, interesting games which all the students would involve in and in a way that they would offer flexibility for the students with different abilities, skills, and personal traits and for educational purposes, they are regarded as the educational game method according to the active learning strategy (Demirel,1999; Ad1güzel, 2010; Mangır, 1993; Kaya \& Elgün, 2015). Educational game method, which has no profit motive, is an active learning method which develops students in cognitive, affective, psycho-motor, physical, and social aspects, has a specific purpose or not, can be carried out with or without rules, and in which students involve voluntarily and willingly (Dönmez, 1999; Hazar, 2005).

The educational game method draws the interest of students with its fun, enjoyable, and interesting aspects which help to develop critical thinking, problem-solving, creativity, imagination, communication, and high-level cognitive skills and to realize permanent and meaningful learning (Kaptan \& Korkmaz, 1999; Kaya \& Elgün, 2015).

The educational game method, with its colorful, fun, enjoyable, and interesting activities, affects students' motivational levels and attitudes towards the school and the course positively (Önen, Demir \& Şahin, 2012; Bayırtepe \& Tüzün, 2007). Students gain many social skills such as cooperation, help, sharing, developing friendship, respecting the individuals with different views, trying to understand them, tolerating individual differences, obeying the rules, advocating personal rights and freedom during the games (Coşkun, Akarsu \& Karaiper, 2012; 
Karamustafaoğlu \& Kaya, 2013). Plays are indispensable activities for personal development in that they develop communicative skills, teach individuals how to express their opinions without hurting, humiliating or harming the people with different world views, fostering their self-confidence, and help them develop sincere and close relationships which are not based on profit motives (Şaşmaz Ören \& Erduran Avc1, 2004; Karamustafaoğlu \& Kaya, 2013).

It is widely known that many affective factors have effects on individuals' learning, academic achievement, critical thinking skills, and scientific process skills (Tuan, Chin \& Sheh, 2005; Köklü, 1996; Wolters \& Rosenthal, 2000; Richardson \& Suinn, 1972). The most important of these affective factors are interest, attitude, motivation, and anxiety. For increasing the levels of learning, it is necessary to keep students' motivation high, to help them have interest in and positive attitudes towards the school, the course, and the teacher, and to keep their levels of anxiety at the ideal levels. Therefore, teachers should use the methods and techniques which would increase the interest and positive attitudes and decrease the levels of anxiety as well as the methods and techniques that would foster learning in their classes. In this way, it would be more likely to reach the targeted learning levels.

When the secondary school students are analyzed in terms of their developmental features, since they are at the concrete operational stage and in transition from the concrete operational stage to the abstract operational stage, using the educational game method which provides a learning by doing and experiencing environment in the learning process would have great benefits in order to offer fun, enjoyable, interesting, meaningful, and permanent learning (Gençer \& Karamustafaoğlu, 2014; Koçyiğit, Tuğluk \& Kök, 2007; Şaşmaz Ören \& Erduran Avc1, 2004).

In a research conducted by Güneş and Güneş (2005), the reasons why students experience difficulties in learning the biology subjects in the science course curriculum are reported to be the factors such as presentation of subjects based on memorization, students' lack of interest in these subjects, insufficiency of motivation and visualization.

It is believed that using the educational game method would be useful to prevent students' loss of interest, decrease of their motivation, their negative attitudes towards the course, the teacher, and the school, increase in the learning anxiety levels stemming from the difficulties while learning a subject including abstract concepts such as the circulatory system in the $6^{\text {th }}$, which corresponces to the transition from the concrete operational stage to the abstract operational stage, they find hard to visualize; and to change the process to the better. 
This research was conducted to study the effects of the instruction of the "Circulatory System", one of the subjects of the $6^{\text {th }}$ grade science course curriculum through the educational game method on students' social skills, attitudes towards the school, and science anxiety levels.

The research problem of the study was determined as "Does the instruction of the "Circulatory System" subject through the educational game method and program-based instruction have any effect on students' social skills, attitudes towards the school, and science anxiety levels?" and the following research questions were aimed to be responded:

1. Is there any significant difference between the social skills of the students being taught through the educational game method or program-based instruction?

2. Is there any significant difference between the attitudes of the students being taught through the educational game method or program-based instruction towards the school?

3. Is there any significant difference between the anxiety levels of the students being taught through the educational game method or program-based instruction?

\section{Methodology}

In this research, the pretest-posttest control group quasi-experimental design, which is one of the experimental research models, was used in order to determine the effectiveness of the educational game method and program-based instruction in teaching "Circulatory System" subject in the $6^{\text {th }}$ grade science course curriculum (Christensen, 2004; McMillan \& Schumacher, 2006; Büyüköztürk vd., 2012). At the beginning of the study, the experimental and the control groups were given the Social Skills Scale, the Sciences Learning Anxiety Scale, and the Attitudes towards School Scale as pretests. While the control group was taught through the program-based instruction, the experimental group was taught through the educational game method and played the game "I found my partner". At the end of the study, the Social Skills Scale, the Science Learning Anxiety Scale, and Attitudes towards School Scale were given to the experimental and the control group again as the posttests. The experimental plan adopted in the study is given in Table 1 .

Table 1 Experimental Plan

\begin{tabular}{llll}
\hline Groups & Pretest & Treatment & Posttest \\
\hline
\end{tabular}




\begin{tabular}{llll}
$\begin{array}{l}\text { Experimental } \\
\text { Group }\end{array}$ & $\begin{array}{l}\text { SSS, SLAS, } \\
\text { ATSS }\end{array}$ & Educational Game Method & $\begin{array}{l}\text { SSS, SLAS, } \\
\text { ATSS }\end{array}$ \\
Control Group & $\begin{array}{l}\text { SSS, SLAS, } \\
\text { ATSS }\end{array}$ & Program-based Instruction & $\begin{array}{l}\text { SSS, SLAS, } \\
\text { ATSS }\end{array}$ \\
\hline
\end{tabular}

\section{The Sample}

The sample of this study consists of 42 participants who were the $6^{\text {th }}$ grade students of two different groups of a state secondary school in the city centre of Erzurum in the 2015-2016 academic year. One of these groups was randomly selected to be the experimental group $(n=20)$ in which the educational game method would be used and the other as the control group $(n=22)$ in which the program-based instruction would be realized.

\section{Data Collection Instruments}

As the data collection instruments of the study,

- SSS, in order to measure the change in the social skills of the students,

- SLAS, in order to measure the change in the science learning anxiety levels,

- ATSS, in order to measure the change in students' attitudes towards the school,

were used.

\section{Social Skills Scale}

It is a four-point Likert scale consisting of 20 items which aim to measure the development in some basic social skills. It measures the social skill behaviours such as eye contact, greeting-saying goodbye, listening, starting a conversation, maintaining the conversation, asking questions, thanking, introducing oneself, convincing, obeying the distribution of work, fulfilling the responsibility in the group, rewarding oneself. The highest score that can be taken from the scale is 80 and students' high scores from it show that the direction of social change is positive. Five experts were consulted about the content validity of the scale and it was reported that it could measure the targeted social skill behaviours. The Cronbach Alpha coefficient of the scale was found as 0.75 before (Kocayörük, 2000; Özabac1, 2006; Yükselgün, 2008; Baydan, Tagay \& Voltan-Acar, 2010). The Cronbach Alpha coefficient of the scale for this study was calculated to be 0,82 . 


\section{Science Learning Anxiety Scale}

The Science Learning Anxiety Scale (SLAS) was developed to measure the levels of anxiety of the secondary school students towards science courses. In accordance with the review of the literature and the opinions of experts taken after students' opinions, a 32-item five-point Likert scale was designed. For validity and reliability analyses, the study was piloted with 844 students. The final version of the scale, obtained after these analyses, consists of student, content, and teaching anxiety, course-avoidance scale, anxiety about the course; and its Cronbach Alpha was found to be 0,85 (Y1ldirım, 2015). For this study, the Cronbach Alpha was found to be 0,94 .

\section{Anxiety towards School Scale}

The 3-point Likert Anxiety towards School Scale which was designed by Coşkun (2004) to measure the attitudes of the 11-15 age students towards the school consists of 10 items, 5 positive and 5 negative. Its Cronbach Alpha was found to be 0,74. The Cronbach Alpha of the scale for the current study was found to be 0,64 .

\section{Data Analysis}

In order to find responses to the pre-determined research questions, the data collected were analyzed through the use of SPSS package program. In the analysis af the data, since the assumptions of the parametric tests were met, the 3 groups t-test was used in order determine whether there were significant differences between the groups in which the educational game method and program-based instruction were used in terms of the students' social skills, their attitudes towards the school and their levels of anxiety about the science courses. The significance level used in statistical analyses was 0.05 .

\section{Treatment}

The predetermined teching methods for the experimental and control group were conducted by the researchers throughout a 10 -hour period in both groups. The pretests were given to the both groups in the last lesson on the same day one week before the treatments started and the posttest were given to them in the first lesson on the same day again one week after the treatments were over by the researchers. In the experimental group, the educational game method was used and they played the "I found my partner" game. On the other hand, the program-based instruction was used in the control group. The treatments in the both groups 
were planned in a way to cover all the learning outcomes determined by the Ministry of National Education. The outcomes the treatments were based on are listed below:

- The learners can explain the structures and organs of the circulatory system with their functions.

- They can illustrate the systemic circulation and pulmonary circulation in a diagram.

- They understand the structure and functions of blood.

- They understand the exchange between different blood groups.

- They research and realize the importance of blood donation for the society.

- They discuss what should be done to keep the circulatory system healthy based on the research findings.

\section{Implemetation of the Program-based Instruction}

In the control group, program-based instruction was implemented for 10 course hours. During the program-based instruction, the activities were designed on the basis of coursebooks. The activities in the coursebooks were done in the order and the way the Ministry of National Education presumes. Short information was given to students in a way would make contributions to the process when necessary.

\section{The Implementation of the Educational Game Method}

In the experimental group, for 10-lesson time the game "I found my partner" was played. The classroom was divided into two big groups, one questions group and one answers group. Each member in the answer group was given one of the concepts in the "Circulatory System" subject in a closed envelope. These concepts were "heart, artery, vein, capillary, erythrocyte, leucocyte, blood-platelet, blood groups, pulmonary circulation, systemic circulation and health of circulatory system". The students in the questions group were given a prediction card. The prediction card is given in Figure 1.

\section{“I FOUND MY PARTNER” GAME PREDICTION CARD}

Name and Name of the Student: 


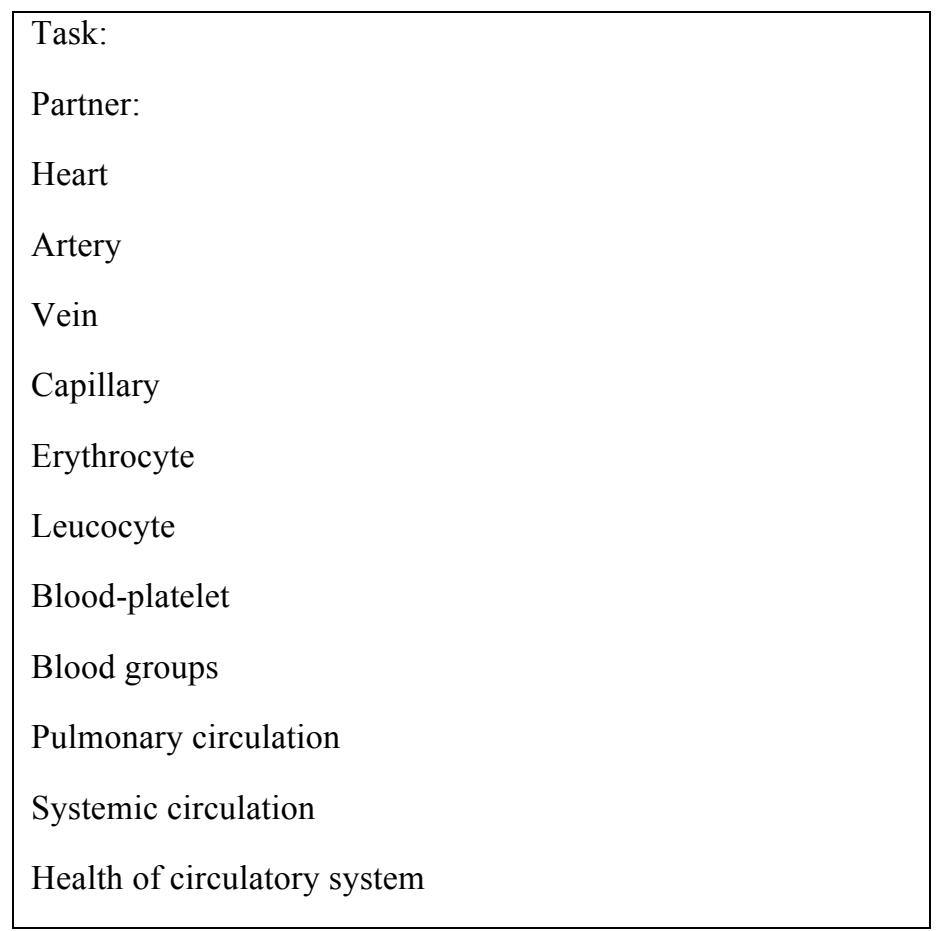

Figure 1: Student's Prediction Card

While the students in the answers group prepared for their own concepts, the students in the questions group had quick overview of the subject and formulated questions in order to ask to the members of the other group. One hour was allotted for this process. The seating system of the students was reorganized in a way those in the answers group members were distributed in the classroom in balanced way. Each member in the questions group spoke to the students in the answers group in turn and tried to guess which concept belonged to them. The students who made their guesses started to fill in prediction cards. Three hours were spent on this part of the game. Afterwards, the questions and answers groups were replaced; the questions group became the answers group and answeres group became questions group. The answers group was given the concepts of the subject in closed envelopes and prediction cards were distributed among the members of the questions group. The groups were given one-hour time to prepare for the next stage. In the following hours of the treatment, the new questions group spoke to the each member of the new answers group and filled in their prediction cards. The members of each group tried to guess the member in the other who held his/her concept and wrote his/her name in the partner section on the prediction card. Later, the prediction cards were collected and the evaluation stage started. The members who could not guess their partners mutually right lost the game. On the other hand, those who guessed their partners right advanced to the next stage. They introduced their concepts to their classmates. Among the partners who guessed their partners right, who had the most right guesses won the game. 


\section{Findings and Comments}

The analysis results of the SSS conducted to measure students' social skills levels before the treatment are given in Table 2.

Table 2 Independent Groups t-Test Results obtained from the SSS Pretest

\begin{tabular}{lllllll}
\hline Group & $\mathbf{N}$ & $\mathbf{X}$ & SD & Df & t & $\mathbf{p}^{*}$ \\
\hline Experimental & 20 & 60,35 & 8,04 & 40 & 0,243 &, 809 \\
Control & 22 & 59,64 & 10,65 & & &
\end{tabular}

When the analysis results of the data obtained from the SSS pretest given in Table 2 are reviewed, it is seen that there is no statistically significant difference between the students who were taught through the educational game method $(X=60,35)$ and program-based instruction $(X=59,64)$ in terms of their social skills before the treatment; $\left(t_{(40)}=0,243 ; p>0,05\right)$.

The SSS was conducted as the posttest after the treatments of the educational game method and program-based instruction in order to measure the effects of these methods on students' social skills and the results of the data collected were given in Table 3.

Table 3 Independent Groups t-Test Results of the Data Obtained from the SSS Posttest

\begin{tabular}{lllllll}
\hline Group & $\mathbf{N}$ & $\mathbf{X}$ & SD & Df & T & $\mathbf{p}^{*}$ \\
\hline Experimental & 20 & 67,90 & 7,68 & 40 & 2,589 &, 013 \\
Control & 22 & 60,45 & 10,57 & & & \\
\hline
\end{tabular}
$\mathrm{p}<0,05$

When the analysis results of the data obtained from the SSS posttest given in Table 3 are reviewed, it is seen that, after the treatment, the social skills levels of the students taught through the educational game method $(X=67,90)$ are statistically significantly higher than the social skills levels of the students taught through the program-based instruction $(X=60,45)$; $\left(\mathrm{t}_{(40)}=2,589 ; \mathrm{p}<0,05 ; \eta^{2}=0,14\right) .14 \%$ of the variance in students' social skills stems from the method followed. According to Cohen (1988), this value is called as major effect.

The analysis results of the data collected through the ATSS conducted in order to measure students' attitudes towards the school before the treatment are given in Table 4. 
Table 4 Independent Groups t-Test Results of the Data Obtained through the ATSS Pretest

\begin{tabular}{lllllll}
\hline Group & $\mathbf{N}$ & $\mathbf{X}$ & SD & Df & t & $\mathbf{p}^{*}$ \\
\hline Experimental & 20 & 21,80 & 3,71 & 40 & $-0,255$ &, 800 \\
Control & 22 & 22,14 & 4,72 & & &
\end{tabular}

When the analysis results of the data obtained through the ATSS pretest given in Table 4 are reviewed, it is seen that there is no statistically significant difference between the students who were taught through the educational game method $(X=21,80)$ and the program-based instruction $(X=22,14)$ in terms of the scores of their attitudes towards the school before the treatment; $\left(\mathrm{t}_{(40)}=-0,255 ; \mathrm{p}>0,05\right)$.

In order to measure the effects of the educational game method and program-based instruction on their attitudes to the school, the ATSS was given to the students as the posttest again. The analysis results of the data obtained from this scale are given in Table 5.

Table 5 Independent Groups t-Test Results of the Data Obtained through ATSS Posttest

\begin{tabular}{lllllll}
\hline Group & $\mathbf{N}$ & $\mathbf{X}$ & SD & Df & t & $\mathbf{p}^{*}$ \\
\hline Experimental & 20 & 25,30 & 2,83 & 40 & 1,687 &, 099 \\
Control & 22 & 23,45 & 4,08 & & &
\end{tabular}

When the results, in Table 5, obtained from the analysis of the data obtained from the ATSS Posttest are analyzed, it is seen that there is no statistically significant difference between the students taught through the use of the educational game method $(X=25,30)$ and those taught through the program-based instruction $(X=23,45)$ in their scores from the attitudes towards to the school scale before the treatment; $\left(\mathrm{t}_{(40)}=1,687 ; \mathrm{p}>0,05\right)$.

The analysis results of the data collected through the SLAS given to the students before the treatment as the pretest in order measure their levels of anxiety about science learning are given in Table 6.

Table 6 Independent Groups t-Test Results of the Data Obtained through the SLAS Pretest

\begin{tabular}{lllllll}
\hline Group & $\mathbf{N}$ & $\mathbf{X}$ & SD & df & T & $\mathbf{p}^{*}$ \\
\hline Experimental & 20 & 42,95 & 13,26 & 40 & 0,808 &, 424 \\
Control & 22 & 39,91 & 11,12 & & &
\end{tabular}


It is seen from the results of the analysis of the SLAS pretest data given in Table 6 that there is no statistically significant difference between the anxiety about science learning levels of the students taught through the use of the educational game method $(X=42,95)$ and those taught through the program-based instruction $(X=39,91)$ before the treatment; $\left(\mathrm{t}_{(40)}=0,808\right.$; $\mathrm{p}>0,05)$.

To measure the effects of the educational game method and program-based instruction on students' levels of anxiety about learning science, the SLAS was given to the students again as the posttest. The results on the analyses of the data collected through this scale are presented in Table 7.

Table 7 Independent Groups t-Test Results of the Data Obtained through the SLAS Posttest

\begin{tabular}{lllllll}
\hline Group & $\mathbf{N}$ & $\mathbf{X}$ & SD & df & T & $\mathbf{p}^{*}$ \\
\hline Experimental & 20 & 29,90 & 8,67 & 40 & $-2,800$ &, 008 \\
Control & 22 & 38,32 & 10,60 & & & \\
\hline
\end{tabular}
$\mathrm{p}<0,05$

From the analysis of the results obtained from the SLAS posttest in Table 7, it is understood that the anxiety about learning science scores of the students taught through the use of the educational game method $(X=29,90)$ are statistically significantly lower than the scores of the students who were taught through the program-based instruction $(X=38,32)$ after the treatment; $\left(\mathrm{t}_{(40)}=-2,800 ; \mathrm{p}<0,05 ; \eta^{2}=0,16\right) .16 \%$ of the variance in science learning anxiety levels of the students stem from the method used. According to Cohen (1988), this value is called as the major effect.

\section{Conclusion and Discussion}

The findings obtained from the study conducted in order to measure the effects of teaching the "Circulatory System" covered in the $6^{\text {th }}$ grade Science course through the use of the educational game method on students' social skills, attitudes towards the school, and science learning anxiety level are discussed in this section and some suggestions are given below to give insights for the future research.

When the results of the analysis of the data collected by the SSS used to measure the effects of the educational game method and the program-based instruction were run through, 
no sitatistically significant difference was found between the social skills of the students in the two groups but it was found that the social skills levels significantly increased in favour of the students who were taught through the educational game method after the treatment (Tables 2 ve 3$)$.

When the findings about the effects of the educational game method and the programbased instruction on students' attitudes towards the school measured by the use of the ATSS are analysed, no siginificant difference was found between their attitudes before and after the study (Tables 4 ve 5). Although the difference was not significant, the attitudes to the school scores of the students in the group the educational game method was used were found to be higher than the scores of the students in the control group in which the program-based instruction was used.

The analysis of the results of the data from the SLAS implemented to identify the effects of the educational game method and the program-based instruction on students' science learning anxieties revealed that before the treatment the science learning anxiety levels of the students in the group the educational game method was used were higher but not at a significant level (Tablo 6). After the treatment, it was found out that the science learning anxiety levels of the educational game method group students were statistically significantly lower than the science learning anxiety levels of the students in the program-based instruction group (Table 7).

This difference between the two group students can be attributed to the benefits of educational games such as contributions to the development of the behaviours like sharing, cooperation, working together, respecting others' opinions, obeying the rules, protecting personal rights, and making friends; fostering motivation, the interest in, love, and positive attitudes towards the course and the school (Cady, 2005; Braude \& Corey, 2006; Coşkun, Akarsu \& Karaiper, 2012; Savaş \& Gülüm, 2014; Karamustafaoğlu \& Kaya, 2013; Önen, Demir \& Şahin, 2012; Bayırtepe \& Tüzün, 2007).

Depending on the experiences the researchers have gained throughout the study, it can be stated that the students with whom the educational game method is used have fun in the classroom, enjoy the lessons, are more willing to engage in activites, develop their communications with their friends, have fewer discipline problems, and want to play the game over and over. It can also be added that similar findings were reached in some of the studies in the literature (Bayat, Kılıçaslan \& Şentürk, 2014; Saracaloğlu \& Aldan Karademir, 2009). 


\section{Suggestions}

In the study, it was found out that the educational game method had positive effects on students' social skills and science learning anxiety levels. In addition to these positive effects, the educational game method has many other benefits to students in different aspects. It is stated in the literature that educational games have great importance in the educational development of the students (Şaşmaz Ören \& Erduran Avc1, 2004; Karamustafaoğlu \& Kaya, 2013; Akandere, 2012; Owens, 1997; Bilen, 2002; Cady, 2005; Braude \& Corey, 2006; Şahin \& Yıldırım, 1999; Özdoğan, 2014). When the relevant literature is reviewed, it is seen that especially the games in virtual platforms are used in education. However, it is believed that the games that will allow students to play actively in the classroom and be able to foster their communication with their friends, express themselves freely, and do the activities beneficial to both affective and psychomotor outcomes will be much more effective in giving the students the targeted basic behaviours in education. Therefore, the educational game method should also be used in the teaching of other subjects in Science course curriculum.

\section{References}

Adıgüzel, Ö. (2010). Eğitimde Yaratıcı Drama. Ankara: Naturel Yayınevi.

Akandere, M. (2012). Eğitici okul oyunları. Ankara: Nobel Yayınevi.

Bayat, S., Kılıçaslan, H., \& Şentürk, Ş. (2014). Fen ve teknoloji dersinde eğitsel oyunların yedinci sınıf öğrencilerinin akademik başarısına etkisinin incelenmesi. Abant İzzet Baysal Üniversitesi Eğitim Fakültesi Dergisi.

Baydan, Y., Tagay, Ö., \& Voltan Acar, N. (Güz 2010). Sosyal beceri programının (BLOCKS) ilköğretim ikinci kademe öğrencilerinin sosyal beceri düzeyleri üzerindeki etkisi. Mehmet Akif Ersoy Üniversitesi Sosyal Bilimler Enstitüsü Dergisi (Elektronik Version). (Erişim Tarihi: 17.12.2015). ISSN: 1309-1387, 2 (3), 19-28.

Bayırtepe, E., \& Tüzün, H. (2007). Oyun-Tabanlı öğrenme ortamlarının öğrencilerin bilgisayar dersindeki başarıları ve öz-yeterlik algıları üzerine etkileri. Hacettepe Üniversitesi Eğitim Fakültesi Dergisi, 33, 41-54.

Bilen, M. (2002). Plandan uygulamaya öğretim. Ankara: Anı Yayıncılık.

Braude, S., \& Corey, L. M. (2006). The confidence game. Science and Children, 44(1), 40-44.

Büyüköztürk, Ş., Kılıç Çakmak, E., Akgün, Ö. E., Karadeniz, Ş. \& Demirel, F. (2012). Bilimsel araştırma yöntemleri. (Geliştirilmiş 13. Bask1). Ankara: Pegem Akademi. 
Cady, S. (2005). Elemental food for thought. The Science Teacher, 72(6), 58.

Çavuş, R., Kulak, B., Berk, H. \& Öztuna Kaplan, A. (2011). Fen ve teknoloji öğretiminde oyun etkinlikleri ve günlük hayattaki oyunların derse uyarlanması. İGEDER Fen ve Teknoloji Öğretmenleri Zirvesi’nde sunulmuş bildiri, İstanbul, Türkiye.

Çepni S. (Ed.). (2011). Fen ve teknoloji öğretimi.(9. Baskı). Ankara: Pegem.

Christison, M.A. (1990). Cooperative learning in the EFL classroom. English Teaching Forum, 28.6-9.

Coşkun, H., Akarsu, B. \& Karaiper, A.İ. (2012). Bilim öyküleri içeren eğitsel oyunların fen ve teknoloji dersindeki öğrencilerin akademik başarılarına etkisi. Ahi Evran Üniversitesi Kırşehir Eğitim Fakültesi Dergisi (KEFAD), 13(1), 93- 109.

Coşkun, L. (2004). Yatılı, taşımalı ve "normal” eğitim yapılan ilköğretim okulu öğrencilerinde akademik başarı, okula ilişkin tutum, algılanan sosyal destek ve davranış-uyum sorunları arasındaki ilişkiler. Yayınlanmamış Yüksek Lisans Tezi. Hacettepe Üniversitesi, Ankara.

Demirel, Ö. (1999). Planlamadan değerlendirmeye öğretme sanatı. Ankara; Pegem A.

Dönmez N. B. (1999). Oyun kitabi. İstanbul: Esin.

Gençer, S., \& Karamustafaoğlu, O. (2014). "Durgun elektrik” konusunun eğitsel oyunlarla öğretiminde öğrenci görüşleri. Araştırma Temelli Etkinlik Dergisi (ATED), 4(2), 72-87.

Güneş, M. H., \& Güneş, T. (2005). İlköğretim öğrencilerinin biyoloji konularini anlama zorlukları ve nedenleri. Ahi Evran Üniversitesi Kırşehir Ĕ̈itim Fakültesi Dergisi, 6 (2).

Hazar, M. (2005). Beden eğitimi ve sporda oyunla eğitim. Ankara: Tutibay Yayıncılık.

Kaptan, F. \& Korkmaz, H. (1999). İlköğretimde Fen Bilgisi Öğretimi. Ankara: Anı Yayıncılık.

Karamustafaoğlu, O., \& Kaya, M:. (2013). Eğitsel oyunlarla “yansıma ve aynalar” konusunun öğretimi: yansımalı koşu örneği. Araştırma Temelli Etkinlik Dergisi, 3(2), 41-49.

Kaya, S., \& Elgün, A. (2015). Eğitsel oyunlar ile desteklenmiş fen öğretiminin ilkokul öğrencilerinin akademik başarısına etkisi. Kastamonu Eğitim Dergisi, 23(1), 329-342.

Kocayörük, A. (2000). İlköğretim Öğrencilerinin Sosyal Becerilerini Geliştirmede Dramanın Etkisi. Yayınlanmamış Yüksek Lisans Tezi. Ankara Üniversitesi Sosyal Bilimler Enstitüsü.

Koçyiğit, S., Tuğluk, M. N. \& Kök, M. (2007). Çocuğun gelişim sürecinde eğitsel bir etkinlik olarak oyun. Atatürk Üniversitesi Kazım Karabekir Eğitim Fakültesi Dergisi, 16, 324342 . 
Köklü, N. (1996). İstatistik kayg1 ölçeği: psikometrik veriler. Eğitim ve Bilim, 20 (102), 45-49.

Mangır, M. (1993). Çocuğun gelişiminde oyunun önemi, Yasadıç̧a Eğitim, 26(16), 14-19.

McMillan, J. H., \& Schumacher, S. (2006). Research in Education: Evidence-Based. Inquiry. Sixth Edition. Boston, MA: Allyn and Bacon.

National Academy of Sciences. (2006). Rising above the gathering storm: Energizing and employing America for a brighter economic future. Washington, DC: National Academy of Sciences/ National Academy of Engineering/Institute of Medicine.

Önen, F. (2005). İlköğretimde basınç konusunda öğrencilerin sahip olduğu kavram yanılgılarının yapılandırmacı yaklaşım ile giderilmesi. Yayımlanmamış Yüksek Lisans Tezi, Marmara Üniversitesi, Eğitim Bilimleri Enstitüsü, İstanbul.

Önen, F., Demir, S., \& Şahin, F. (2012). Fen öğretmen adaylarının oyunlara ilişkin görüşleri ve hazırladıkları oyunların değerlendirilmesi. Ahi Evran Üniversitesi Kırşehir Eğitim Fakültesi Dergisi (KEFAD), 13(3), 299-318.

Owens, K. D. (1997). Playing to learn: science games in the classroom. Scince Scope, 20(5), 31-33.

Özabacı, N. (2006). Çocukların sosyal becerileri ile ebeveynlerin sosyal becerileri arasındaki ilişki üzerine bir araştırma. Fırat Üniversitesi Sosyal Bilimler Dergisi, Cilt 16, Sayı.1, s.163-179.

Özdoğan, B. (2014). Çocuk ve oyun. Ankara: Anı Yayıncılık.

Richardson, F.C., \& Suinn, R.M. (1972). The mathematic anxiety rating scale: psychometric data. Journal of Counseling Psychology, 19 (6), 551-554.

Şahin, Y. T., \& Yıldırım, S. (1999). Öğretim teknolojileri ve materyal geliştirme. Ankara: Anı Yayınc1lık.

Saracaloğlu, A. S. \& Aldan Karademir, Ç. (2009). Eğitsel oyun temelli fen ve teknoloji öğretiminin öğrenci başarısına etkisi. VIII. Ulusal Sınıf Öğretmenliği Eğitimi Sempozyumu, Bildiri Kitabı. 21-23 Mayıs 2009. Osmangazi Üniversitesi: Eskişehir. 1098-1107.

Şaşmaz Ören, F., \& Erduran Avcı, D. (2004). Eğitimsel oyunla öğretimin fen bilgisi dersi “güneş sistemi ve gezegenler” konusunda akademik başarı üzerine etkisi. Ondokuz Mayıs Üniversitesi Eğitim Fakültesi Dergisi, 18, 67-76. 
Savaş, E., \& Gülüm, K. (2014). Geleneksel oyunlarla öğretim yöntemi uygulamasının başarı ve kalıc1lı üzerine etkisi. Trakya Üniversitesi Sosyal Bilimler Dergisi, 16(1), 175-194.

Sökmen N., Bayram, H., Solan, Ü., Savc1, H., \& Gürdal, A. (1997). Kavram haritasının fen bilgisi başarısına etkisi. Marmara Üniversitesi Eğitim Fakültesi Dergisi, 142-149.

Tuan, Chin \& Sheh (2005). The development of a questionnaire to measure students' motivation towards science learning. International Journal of Science Education, 27(6), 634-659.

Uzuntiryaki, E., Çakır, H., \& Geban, Ö. (2001). Kavram haritaları ve kavramsal değişim metinlerinin öğrencilerin "asit-bazlar” konusundaki kavram yanılgılarının giderilmesine etkisi. Yeni Bin Yılın Basında Fen Bilimleri Eğitimi Sempozyumu, (7-8 Eylül 2001), İstanbul. Bildiriler Kitabı, 281-284, 2001 Maltepe Üniversitesi Eğitim Fakültesi.

Wolters, C.A., \& Rosenthal, H. (2000). The relation between students' motivational beliefs and their use of motivational regulation strategies. International Journal of Educational Research, 33, 801-820.

Yıldırım, B. (2015). Fen bilimleri öğrenme kaygı ölçeği: geçerlilik ve güvenirlik çalışması. Fen Bilimleri, 3 (1).

Yükselgün, Y. (2008). İlköğretim dördüncü ve beşinci sınıf öğrencilerinin internet kullanım durumlarına göre saldırganlık ve sosyal beceri düzeylerinin incelenmesi. Yayımlanmamış Yüksek Lisans Tezi, Eskişehir Osmangazi Üniversitesi Sosyal Bilimler Enstitüsü, Eskişehir. 